\title{
Mitigating nitrogen pollution from global croplands with cost-effective measures
}

\section{Baojing Gu ( $\sim$ bjgu@zju.edu.cn )}

Zhejiang University https://orcid.org/0000-0003-3986-3519

\section{Xiuming Zhang}

The University of Melbourne https://orcid.org/0000-0002-1961-3339

\section{Shu Lam}

University of Melbourne https://orcid.org/0000-0001-7943-5004

\section{Yingliang Yu}

Jiangsu Academy of Agricultural Sciences

\section{Hans van Grinsven}

PBL Netherlands Environmental Assessment Agency https://orcid.org/0000-0001-7304-0706

\section{Shaohui Zhang}

Beihang University https://orcid.org/0000-0003-2487-8574

\section{Xiaoxi Wang}

Zhejiang University https://orcid.org/0000-0003-2678-9217

\section{Jiakun Duan}

Zhejiang University

\section{Alexander Bouwman}

PBL Netherlands Environmental Assessment Agency

Jianming $\mathrm{Xu}$

Zhejiang University https://orcid.org/0000-0002-2954-9764

\section{Deli Chen}

University of Melbourne https://orcid.org/0000-0001-6767-1376

\section{Mark Sutton}

NERC Centre for Ecology and Hydrology

\section{Sitong Wang}

Zhejiang University

\section{Benjamin Bodirsky}

Potsdam Institute for Climate Impact Research https://orcid.org/0000-0002-8242-6712

\section{Physical Sciences - Article}

Keywords: nitrogen pollution, cropland, pollution mitigation 
Posted Date: August 18th, 2021

DOl: https://doi.org/10.21203/rs.3.rs-806169/v1

License: (c) (i) This work is licensed under a Creative Commons Attribution 4.0 International License. Read Full License 
Mitigating nitrogen pollution from global croplands with cost-effective measures

Baojing $\mathrm{Gu}^{1,2, *}$, Xiuming Zhang ${ }^{3}$, Shu Kee $\mathrm{Lam}^{3}$, Yingliang $\mathrm{Yu}^{4}$, Hans M. van Grinsven $^{5}$, Shaohui Zhang ${ }^{6,7}$, Xiaoxi Wang ${ }^{8}$, Benjamin Leon Bodirsky ${ }^{9}$, Sitong Wang ${ }^{1}$, Jiakun Duan ${ }^{1}$, Lex Bouwman ${ }^{5}$, Jianming $\mathrm{Xu}^{1}$, Deli $\mathrm{Chen}^{3}$, Mark A. Sutton ${ }^{10}$

${ }^{1}$ College of Environmental and Resource Sciences, Zhejiang University, Hangzhou, 310058, China

${ }^{2}$ Zhejiang Provincial Key Laboratory of Agricultural Resources and Environment, Zhejiang University, Hangzhou 310058, China

${ }^{3}$ School of Agriculture and Food, The University of Melbourne, Melbourne, Victoria 3010, Australia

${ }^{4}$ Key Laboratory of Agricultural Environment of the Lower Reaches of the Yangtze River, Institute of Agricultural Resources and Environment, Jiangsu Academy of Agricultural Sciences, Nanjing 210014, PR China

5 PBL Netherlands Environmental Assessment Agency, PO BOX 30314, 2500 GH The Hague, The Netherlands

6 School of Economics and Management, Beihang University, 37 Xueyuan Road, 100091, Beijing, China

7 International Institute for Applied Systems Analysis, Schlossplatz 1, A-2361, Laxenburg, Austria

8 Department of Agricultural Economics and Management and China Academy for Rural Development, Zhejiang University, Hangzhou, 310058, China

${ }^{9}$ Potsdam Institute for Climate Impact Research (PIK), PO Box 6012 03, D-14412 Potsdam, Germany

${ }^{10}$ UK Centre for Ecology \& Hydrology, Edinburgh Research Station, Bush Estate, Penicuik, Midlothian, EH26 0QB, UK

*Corresponding authors: bjgu@zju.edu.cn (B.G.)

Cropland is one of the major sources of global nitrogen pollution ${ }^{1,2}$. Mitigating nitrogen pollution from global croplands is a grand challenge because of the nature of non-point source pollution from millions of farms and the lack of financial resources and scientific knowledge of farmers ${ }^{3}$. Here we synthesize 683 studies worldwide and identify 11 key measures which can reduce $30-70 \%$ of nitrogen pollution while increasing crop yield and nitrogen use efficiency by $10-30 \%$ and 20-60\%, respectively. Adoption of these measures would produce 14 million tonnes (Tg) more crop nitrogen with $28 \mathrm{Tg}$ less nitrogen fertilizer and $27 \mathrm{Tg}$ less nitrogen pollution to the environment in global croplands in 2015. However, to achieve these potentials, innovative policies such as a nitrogen credit system (NCS) should be implemented to incentivize and subsidize the adoption of these measures given the mismatch between benefits for the whole society while the abatement cost only for farmers. Full implementation of the best-fitted measures could achieve 306 billion USD benefits on ecosystem, human health and climate globally, with net mitigation costs of only 21 billion USD given 35 billion USD fertilizer saving cost has offset $2 / 3$ of the total mitigation cost. The large benefit-to-cost ratio suggests the feasibility and urgency to implement the NCS and Tier approaches could help to implement the most cost-effective measures on regional and local scales.

Feeding the growing and increasingly wealthy population brings huge pressure on 
global food production ${ }^{4}$. To increase food supply, intensified agriculture has used more and more nitrogen fertilizers and manure ${ }^{2}$. Nevertheless, over half of these nitrogen inputs is lost to the environment, close to the annual total chemical nitrogen fertilizer used globally, leading to severe air (e.g. fine particle matters, $\mathrm{PM}_{2.5}$ ) and water (e.g. eutrophication) pollution, soil acidification, climate change, ozone depletion and biodiversity loss ${ }^{1,5}$. Therefore, reducing nitrogen loss from croplands can not only increase direct economic returns from fertilizer saving but also improve human health and other welfare linked to ecosystem health and climate change ${ }^{6}$.

Mitigation of nitrogen pollution from croplands has attracted global attention ${ }^{7}$. Best management practices have been developed such as 4R nutrient stewardship (right fertilizer type, right amount, right placement, and right time) and soil testing to precisely apply fertilizer to the soil ${ }^{8}$. However, these advanced management and technologies are seldom fully implemented, a high heterogeneity of best-practices on the local scale, and high implementation cost for farmers ${ }^{2,9}$. Thus, we attempted to solve these challenges through identifying the best measures to abate nitrogen pollution and estimate the cost and benefit to facilitate the implementation of these measures. We first identified measures through a global meta-analysis and quantified their potentials to abate nitrogen pollution in global croplands; second, calculated the implementation cost of measures and social benefit to facilitate the implementation of these measures; finally, recommended the most cost-effective measures to different global regions using Tier approaches.

\section{Mitigation potential}

Through conducting a meta-analysis of 683 papers published in the past two decades, we identified 11 key measures that can mitigate nitrogen pollution from croplands across global regions (Fig. 1, Fig. S1-S11). These measures can be divided into four groups: 4R nutrient stewardship, additive (enhanced efficiency fertilizer, organic amendment), crop species (legume rotation, new cultivar) and biophysical management (optimal irrigation, no-tillage, buffer zone). Implementation of these measures would reduce the nitrogen losses via multiple pathways: emission of ammonia $\left(\mathrm{NH}_{3}\right)$, nitrogen oxides $\left(\mathrm{NO}_{\mathrm{x}}\right)$ and nitrous oxide $\left(\mathrm{N}_{2} \mathrm{O}\right)$, reactive nitrogen $\left(\mathrm{N}_{\mathrm{r}}\right)$ leaching and $\mathrm{N}_{\mathrm{r}}$ runoff. Reduction of nitrogen losses varied with the loss pathway and associated measures. Although some measures may increase nitrogen losses in certain pathways (Fig. 1), most of the measures can effectively reduce nitrogen losses by $30-70 \%$ (Table 1, Fig. 1) and increase yield and nitrogen use efficiency (NUE) by $10-30 \%$ and $20-60 \%$, respectively. Enhanced efficiency fertilizers, 4R nutrient stewardship, irrigation and legume rotation have better overall performance on reduction of nitrogen pollution (Table 1). Generally, mitigation measures could reduce nitrogen loss, which save nitrogen for crop use that would increase yield and the NUE. For instance, the EEF can totally save $47 \%$ of the total nitrogen loss that would increase $25 \%$ of crop yield and $18 \%$ of the NUE.

Using $\mathrm{CHANS}^{10}, \mathrm{MAgPIE}^{11}$ and IMAGE $^{12}$ modelling, we estimated that implementation of these mitigation measures on global croplands would reduce $\mathrm{N}_{\mathrm{r}}$ emission to the air $\left(\mathrm{NH}_{3}, \mathrm{NO}_{\mathrm{x}}\right.$, and $\left.\mathrm{N}_{2} \mathrm{O}\right)$ and water (runoff to surface water and leaching to ground water) by 11 and $17 \mathrm{Tg} \mathrm{N}$, respectively, in 2015 (Fig. 2). We also estimate a $9 \mathrm{Tg} \mathrm{N}$ reduction of $\mathrm{N}_{2}$ emissions, which is an unreactive gas that would not damage the environment, but saves the use of $\mathrm{N}_{\mathrm{r}}$ fertilizers that can also reduce the upstream cost on fertilizer production and the related emission of pollutants and 
greenhouse gas $(\mathrm{GHG})^{1}$. These changes would reduce total $\mathrm{N}_{\mathrm{r}}$ input to global croplands by $23 \mathrm{Tg} \mathrm{N}$ in 2015, and increase $\mathrm{N}_{\mathrm{r}}$ harvest by $14 \mathrm{Tg} \mathrm{N}$, resulting in an increase of NUE from $42 \%$ to $55 \%$ globally. These $\mathrm{N}_{\mathrm{r}}$ reduction measures recycle $11 \mathrm{Tg} \mathrm{N}$ to croplands through manure and straw addition and reduce deposition and chemical fertilizers input to croplands by $6 \mathrm{Tg} \mathrm{N}$ and $28 \mathrm{Tg} \mathrm{N}$, respectively.

Reduction of $\mathrm{N}_{\mathrm{r}}$ input and losses varied globally (Fig. 2). The largest reduction of $\mathrm{N}_{\mathrm{r}}$ input and losses are found in East and South Asia, and Southeast Asia. It suggests the over-use of nitrogen fertilizer in these global regions. Less reduction stems from highincome regions such as the European Union, Australia and North America where $\mathrm{Nr}$ uses in croplands are close to the optimal level, despite there is still potential to further reduce $\mathrm{N}_{\mathrm{r}}$ input and loss ${ }^{13}$. $\mathrm{N}_{\mathrm{r}}$ input should be increased in Africa, Latin America, East Europe, and Middle Asia, where the $\mathrm{N}_{\mathrm{r}}$ use has been relatively low, especially in Africa where too little nitrogen fertilizer use has depleted the soil nitrogen there ${ }^{2}$. On the contrary, crop yield and the NUE are expected to be increased in East and South Asia due to the optimization of nitrogen use (Fig. 2). While the NUE would be only slightly increased in other global regions since both high-income countries such as US and lowincome countries from Africa already have high $\mathrm{NUE}^{13}$. Detailed changes of nitrogen budget on national and regional scales can be found in Extend Data Fig. 1-3.

\section{Mitigation cost and benefit}

The net mitigation cost of these measures mainly including the labor cost, material cost and services is estimated at 21 billion USD in 2015 globally (Fig. 3a). These costs represent the net benefits from fertilizer savings that are estimated at 35 billion USD, which means the initial implementation cost is around 56 billion USD. Fertilizer saving contribute to $2 / 3$ of the total implementation cost of these measures. China alone would require 5 billion USD to implement the mitigation measures, followed by India which needs 3 billion USD; these two countries are the largest consumers of $\mathrm{N}_{\mathrm{r}}$ fertilizers and emitters of $\mathrm{N}_{\mathrm{r}}$ to the environment (Fig. 4). The net mitigation cost of other countries is less than 1 billion USD, mainly due to small amount of $\mathrm{Nr}$ loss and/or more advanced agricultural machinery and well-trained farmers, allowing a low transaction cost to implement these measures. These $\mathrm{N}_{\mathrm{r}}$ abatement measures such as the $4 \mathrm{R}$ nutrient stewardship would be implemented by farmers who would have to change management practices on their lands ${ }^{3}$. Farmers must invest money to achieve these changes if there is no government or public support. However, in competitive markets that do not internalize the pollution damage costs, implementation of these mitigation measures, which reduce farmers' profits, is unlikely ${ }^{3}$.

Despite large mitigation costs for farmers, the overall benefits on human health, ecosystem, and climate change due to abatement of $\mathrm{Nr}$ losses from croplands are approximate 15 times that of the cost, i.e., 306 billion USD for the whole society (Fig. 3a, Table S2). About 43\% of the benefit (132 billion USD) stems from improved human health, most importantly through avoiding respiratory diseases due to $\mathrm{PM}_{2.5}$ pollution. The remaining 55\%, about 170 billion USD, stem mainly from reduced damages to ecosystem services such as eutrophication, which reduces the recreation value. Climate benefits are only approximately 5 billion USD, and the abatement of $\mathrm{N}_{\mathrm{r}}$ emission in some regions can even aggravate global warming through e.g., reduction of carbon sequestration in natural ecosystems ${ }^{14}$. These mitigation benefits are for the whole society, and the high benefit-to-cost ratio suggests the potential to implement these measures. More details of the uncertainties of cost and benefit of mitigating nitrogen 
pollution can be found in Extend Data Fig. 3 and 4.

\section{Incentivizing the implementation}

Societal benefits of mitigating $\mathrm{N}_{\mathrm{r}}$ losses are for the whole society while the mitigation measures have to be implemented by farmers. This mismatch requires a financial incentive for farmers, especially smallholders who lack financial resources, to increase their adoption of mitigation measures. One potential approach is a Nitrogen Credit System (NCS) that gathers the financial budget from the whole society who benefit from the $\mathrm{N}_{\mathrm{r}}$ abatement and food supply. The lower limit of the financial budget is the sum of net implementation cost and the transition cost to allocate the financial budget to farmers, whereas the upper limit is the total societal benefits of abatement of $\mathrm{N}_{\mathrm{r}}$ loss. As the benefit is about 15 times that of the costs, the NCS budget can vary based on the local financial conditions (Fig. 3), suggesting the potential and feasibility to implement the NCS. The government manages the NCS and assigns the required budget to stakeholders, scientists identify the cost-effective measures for farmers, and a nitrogen credit board authorized by governments manages the implementation ${ }^{3}$. In fact, agricultural subsidies are commonly used in many countries to maintain the food security. The NCS could be combined with agricultural production subsidies to build green agricultural subsidies ${ }^{15}$.

The NCS can not only be applied to $\mathrm{N}_{\mathrm{r}}$ reduction but also to broader pollution control, including other agricultural pollution such as phosphorus, potassium, heavy metals, and other sectors such as livestock production ${ }^{16}$. A more comprehensive credit system such as Environmental Credit System (ECS) to ensure environmentally-friendly food production is critical for agricultural sustainability. The credit system is an initiative for the solution to the tragedy of common-pool resource ${ }^{17}$. Environment is a typical common-pool resource, while food supply is essential for human beings. We may have to subsidize farmers to produce food without compromising environmental quality given the essential of food production for human and it is costly for farmers to control pollution. Thus, the polluter-pays-principle (i.e., pollution tax rather than production subsidy) applied to reduce industrial pollution ${ }^{18}$, may be not suitable for agricultural pollution control. Therefore, ensuring the synergy of food production and environmental protection via the credit system is one of the key strategies for achieving the global sustainable goals ${ }^{4}$.

\section{Feasibility of implementation}

The implementation barriers and costs of mitigation measures vary strongly. We therefore grouped the mitigation measures into four Tiers with increasing implementation challenges from lower to higher Tiers (Table 1, Table S4). The lower the tiers, the easier and cheaper for farmers to adopt. Use of enhanced efficiency fertilizers (EEFs) is a typical Tier 1 measure, government can subsidize EEFs to make them the same or lower price compared to traditional fertilizers, and farmers would prefer using these new EEFs given they can earn more with the same or lower input ${ }^{19}$. Similar tiers can also be applied to the use of amendment and legume rotation, which are simple for farmers, but subsidies would be required from governments. Tier 1 can be applied in all global regions, regardless of the farm size or farmers' knowledge level (Table 1). Therefore, Tier 1 measures have the largest potential to be applied on the global scale and contribute to about half the mitigation potential on $\mathrm{N}_{\mathrm{r}}$ input and loss to the environment (Fig. 5). Beside the 200 billion USD benefit, implementation of Tier 1 measures can save approximate 19 billion USD of cost mainly due to fertilizer saving 
and legume rotation that can save materials such as pesticide uses (Fig. 3b).

Compared to the Tier 1 measures, it is harder for farmers to adopt measures from other Tiers (Fig. 3b). Implementation of the $4 \mathrm{R}$ measures requires extra inputs from farms such as knowledge exchange, labor, and machinery ${ }^{9}$. Knowledge requires long-term training, which is more attractive to large-scale farmers but less for smallholders given the scale effect of fixed inputs including the knowledge, machinery, and other fixed assets $^{20}$. Smallholders would have to input their labor to the off-farm sector where they receive higher income. These would cost approximate 17 billion USD to implement Tier 2 measure globally despite they may bring 59 billion USD societal benefits. Thus, both the implementation ratio and mitigation potential are much smaller than that of Tier 1 (Fig. 5). For Tier 3 and 4 measures, more advanced knowledge and facilities are required, which usually can only be adopted by professional farmers with large-scale farming, especially for Tier 4, which is rarely applicable to pollution mitigation at the global scale.

There are many options to incentivize the implementation of mitigation measures other than the Tier approach under the NCS. Subsidies for measures might be from an economic perspective but may not be the most efficient instrument. For example, the European Common Agricultural Policy performs poorly in practice when referring to higher Tiers ${ }^{21}$. The polluter-pays-principle is recommended to avoid rebound effects in up-stream sectors and consumption ${ }^{18}$. These subsidies also require taxation to counterfinance, leading to efficiency losses elsewhere, and do not target end-point pollution. These challenges may limit the implementation of the NCS, especially for the higher Tiers.

However, the measures classified as the lower Tiers are usually top-down implemented, which requires little involvement of farmers ${ }^{22}$. When the extent of reduction of nitrogen losses increases, higher Tiers are required, which may be integrated with other schemes such as nitrogen surplus tax ${ }^{23}$. An open framework to adopt an appropriate scheme considering the costs of compensation and the mitigation potential by Tiers is crucial. A nitrogen surplus tax in combination with payments for other ecosystem services may be a suitable instrument for higher Tiers, especially in large-holder farms in developed countries. It regulates at the point of emission, is fair based on the polluter-pays principle, and generates tax revenues that can be used to improve food security.

\section{Methods}

\section{Data collection and compilation}

We conducted a literature search of peer-reviewed publications after year 2000 from the Web of Science. The keywords used in the search included "nitrogen OR non-point source pollution", "mitigation OR abatement", and "cropland OR farmland". Studies were included if they met the following criteria: (i) the sample means of the nitrogen loss from targeted pathways, yield or NUE were reported for both the control and the treatment groups; (ii) details on experimental location, design and conditions were given to enable cross-checking of duplicate publications; (iii) only field experiments were included.

We included in our analyses a total of 1521 observations from 683 publications. The treatment groups (and categories) and the control of various management practices were: enhanced efficiency fertilizers (urease inhibitors, nitrification inhibitors, double 
inhibitors (urease and nitrification inhibitors), and coated or controlled release fertilizers) were compared with their counterparts without inhibitors or coatings (control); organic amendments (biochar, manure and crop residues) were compared with urea (control); the highest fertilizer application rate used in the experiment was regarded as the control, whereas the other rates converted to the percentage reduction $(<25 \%, 25-49 \%, 50-74 \%$ and $\geq 75 \%$ ) relative to the control; for fertilizer type, urea was treated as the control and the non-urea treatments (control) were categorized into ammonium or nitrate based fertilizers, manure and compost; splitting frequency of fertilizer application was compared with single application (control); deep placement of fertilizers was compared with surface broadcast or topdressing (control); incorporation of legume into a rotation was compared with non-legume rotation (control); a crop variety with a high NUE was compared to that with low NUE (control); no-tillage was compared with conventional tillage (control); drip irrigation or optimal irrigation was compared with normal irrigation (control); wetlands or ponds with a buffer zone were compared with those without (control). All data were extracted from text or tables directly, or from figures using WebPlotDigitizer 4.2.

\section{Meta-analysis}

The natural $\log$ of the response ratio $\left(r=\bar{x}_{t} / \bar{x}_{c}\right.$, where $\bar{x}_{t}$ and $\bar{x}_{c}$ are the means of the treatment and control groups, respectively) was used as a metric for the analysis of treatment effects on $\mathrm{N}$ loss from various pathways, yield and NUE. The results were reported as the percentage change under treatment effects $((r-1) \times 100)$. Negative percentage changes indicate a decrease in the variables due to the management practices whereas positive changes indicate an increase. We followed a commonly adopted randomization resampling procedure ${ }^{24}$ and generated mean effect sizes and $95 \%$ confidence intervals by bootstrapping (4,999 iterations $)^{25}$ using the software MetaWin $2.1^{26}$. In previous meta-analyses, the effect sizes reported were weighted by the inverse of the pooled variance ${ }^{27}$, replication ${ }^{28}$ or unweighted ${ }^{29}$. The studies included in our database did not always include published variances or replications, so the unweighted approach $^{29}$ was adopted in our analysis. The effects of management practices on $\mathrm{N}$ losses, yield and NUE were considered significant if the confidence intervals did not overlap with zero ${ }^{24}$.

\section{Cropland $\mathrm{N}$ budget}

Cropland $\mathrm{N}$ budget database for each country/region in 2015 was established first to identify current cropland $\mathrm{N}$ input, output and NUE. $\mathrm{N}$ inputs $\left(N_{\text {input }, i}\right)$ to cropland include five elements, which are $\mathrm{N}$ fertilizer $\left(N_{f e r, i}\right)$ input, manure $\mathrm{N}$ input $\left(N_{\text {man,i }}\right)$, biological $\mathrm{N}$ fixation $\left(N_{f i x, i}\right)$, atmospheric $\mathrm{N}$ deposition $\left(N_{\text {dep }, i}\right)$, and irrigation $\left(N_{\text {irr }, i}\right)$. $\mathrm{N}$ outputs from cropland are divided into four elements, which are crop harvest $\left(N_{\text {harvest }, i}\right), \mathrm{N}$ gas emission $\left(N_{\text {gas }, i}\right), \mathrm{N}$ leaching $\left(N_{\text {leach }, i}\right)$ and $\mathrm{N}$ runoff $\left(N_{\text {runoff }, i}\right)$. Cropland NUE is defined here as the ratio of harvested crop $\mathrm{N}$ to total cropland $\mathrm{N}$ input. On the premise of meeting current food demand and ensuring a target harvest $\mathrm{N}$ $\left(N_{\text {target harvest }, i}\right)$ consistent with the Sustainable Development Goals, a target cropland NUE $\left(N U E_{\text {target }, i}\right)$ is assumed to represent a reasonable index of the implementation of current best technologies and management practices. Definition of the target $N U E_{i}$ and $N_{\text {harvest }, i}$ allow us to calculate the unnecessary anthropogenic $\mathrm{N}$ input $\left(\Delta N_{\text {input }, i}\right)$ to the cropland in different countries and regions.

$$
N_{\text {input }, i}=N_{f e r, i}+N_{\text {man }, i}+N_{f i x, i}+N_{\text {dep }, i}+N_{\mathrm{irr}, \mathrm{i}}
$$




$$
\begin{gathered}
N_{\text {output }, i}=N_{\text {harvest }, i}+N_{\text {gas }, i}+N_{\text {leach }, i}+N_{\text {runoff }, i} \\
N_{\text {target input }, i}=N_{\text {target harvest }, i} / N U E_{\text {target }, i} \\
\Delta N_{\text {input }, i}=N_{\text {input }, i}-N_{\text {target input }, i}
\end{gathered}
$$

\section{The reduction potential of $\mathbf{N}$ fertilizer use}

The estimation of global and regional fertilizer reduction potential is based on the difference between the current and optimal fertilizer use with best cropland $\mathrm{N}$ management practices.

$$
\Delta N_{f e r, i, k}=\Delta N_{\text {input }, i, k}+\Delta N_{\text {man }, i, k}-\Delta N_{\text {dep }, i}
$$

where $k$ means the best-fitted combination of multiple options; we assume the $N_{\text {fix }, i}$ and $N_{\text {irr,i }}$ change little, while manure recycling to cropland $\left(\Delta N_{\text {man,i,k }}\right)$ could contribute to the reduction in chemical fertilizer input $\left(\Delta N_{f e r, i, k}\right)$, the change of $\mathrm{N}$ deposition $\left(\Delta N_{\text {dep }, i}\right)$ to cropland is assumed to be corrected linearly with the reduction of $\mathrm{Nr}$ emission $\left(\Delta E_{i, j}\right)$. Nfer cannot be negative and any $\Delta \mathrm{Nfer}>\mathrm{Nfer}$ has to be set to 0 .

\section{Cropland $\mathrm{Nr}$ mitigation potential}

Based on the integrated model results of CHANS, MagPIE and IMAGE, we identified the share of different forms of $\mathrm{N}$ loss in different countries/regions. Implementation of new options could change the share of different $\mathrm{N}$ loss. The calculation of the $\mathrm{Nr}$ mitigation potential is based on the mitigation efficiency of selected mitigation options for different regions and the cropland $\mathrm{N}$ mass balance integrated with the CHANS model. The reduction of cropland $\mathrm{N}$ loss in the form of $\mathrm{NH}_{3}, \mathrm{NO}_{\mathrm{x}}, \mathrm{N}_{2} \mathrm{O}, \mathrm{N}$ leaching and $\mathrm{N}$ runoff in country/region $i$ is calculated as:

$$
\Delta E_{i, j}=A_{i, j, k} *\left[E F_{i, j, k} \times \eta_{i, j, k} \times X_{i, j, k}\right]
$$

where $j$ represents the form of $\mathrm{N}$ loss $\left(\mathrm{NH}_{3}, \mathrm{NO}_{\mathrm{x}}, \mathrm{N}_{2} \mathrm{O}\right.$ and $\mathrm{N}$ leaching and $\mathrm{N}$ runoff) from cropland; $A_{i, j, k}$ is the cropland activity data (fertilizer use, cropping area or production); $E F_{i, j, k}$ is the corresponding uncontrolled emission factor; $\eta_{i, j, k}$ is the specific abatement efficacy; $X_{i, j, k}$ is the implementation rate of the abatement technique or options, and the baseline is 0 , i.e., no implementation of advanced measures.

\section{Cost-benefit analysis}

The mitigation costs for N pollution from global croplands via the NCS in this study is defined as a direct expenditure (the sum of investment costs and operation costs) for implementation of the best-fitted measure to reduce $\mathrm{N}$ loss from global croplands. Here we mainly refer to the database and methodology of the cost assessment from the online Greenhouse Gas and Air Pollution Interactions and Synergies (GAINS) model (https://gains.iiasa.ac.at/models/index.html) to calculate the global and regional abatement costs. Country-specific agricultural conditions and farming practices have been considered in GAINS by taking into account local labor costs, energy prices, farm size and costs of by-products etc. All cost figures from the model calculations are in constant 2017 US\$ in this study. A detailed description of the GAINS model and cost calculation could be found in Klimont et $\mathrm{al}^{30}$. The annual implementation cost $\left(\mathrm{IC}_{\mathrm{i}, \mathrm{k}}\right)$ in country/region $i$ is calculated as:

$$
I C_{i, k}=\Delta E_{i, k} * U C_{i, k}
$$

where $U C_{i, k}$ represents the integrated unit abatement cost of best-fitted mitigation options to reduce cropland $\mathrm{N}$ loss in country/region $i$, which is derived from the online GAINS model database and adjusted according to country-specific farming practices. 
The societal benefits of mitigating $\mathrm{N}$ pollution from global croplands via the NCS in this study is defined as the sum of avoided damage cost for human health $\left(\mathrm{HH}_{\text {benefit }}\right)$, ecosystem health ( $\left.\mathrm{EH}_{\text {benefit }}\right)$, GHG mitigation benefit ( $\left.\mathrm{GHG}_{\text {benefit }}\right)$, as shown in Eq. (8),

$$
S O C_{\text {benefit }, i, k}=H H_{\text {benefit }, i, k}+E H_{\text {benefit }, i, k}+G H G_{\text {benefit } i, k}
$$

A number of US and EU studies have examined the damage cost of $\mathrm{Nr}$ effect on ecosystems ${ }^{31-38}$. Currently we do not have available costs and benefits data for other nations of the world. For this reason, we assume the unit $\mathrm{N}_{\mathrm{r}}$ damage costs (Table $\mathrm{S} 1$ ) to the ecosystems in the EU and USA are also applicable to other countries after correction for differences in the willingness to pay (WTP) for ecosystem services to assess the benefits and tradeoffs associated with N-related management actions for different areas, as shown in Eq. (9)

$$
E H_{\text {benefit }, i}=\Delta E_{i, j} * \partial_{E U} * \frac{W T P_{i}}{W T P_{E U}} * \frac{P P P_{i, j}}{P P P_{i, j}}
$$

where $\partial_{\mathrm{EU}}$ is the estimated unit ecosystem damage cost of $\mathrm{Nr}$ emission in Europe based on the European Nitrogen Assessment ${ }^{34,}{ }^{36} ; W T P_{i}$ and $W T P_{E U}$ are the values of the willingness to pay (WTP) for ecosystem service in country $i$ and Europe; $P P P_{i, j}$ and $P P P_{E U, j}$ stand for the PPP (purchasing power parity) of country $i$ and the EU. The welfare implications of transforming damages are based on WTP.

For health benefits, we derived the unit health damage costs of $\mathrm{Nr}$ emission in 2015 from the cause-specific integrated exposure-response (IER) functions. The IER functions are developed from epidemiological data that estimate the relative risk of mortality from exposure to $\mathrm{PM}_{2.5}$ in different global regions. Generally, the IERs are fitted using a modified power function, with an approximately linear response when $\mathrm{PM}_{2.5}$ concentration is higher than $25 \mu \mathrm{g} / \mathrm{m}^{3}$. More detailed calculation of the health damage from $\mathrm{PM}_{2.5}$ pollution can be found from the World Bank report and the GBD website (http://ghdx.healthdata.org/). The calculation of Health benefits from cropland $\mathrm{N}$ management is shown in Eq. (10):

$$
H H_{\text {benefit }, i, j}=\Delta E_{\mathrm{i}, \mathrm{j}} * \mathrm{HCost}_{\mathrm{i}, \mathrm{j}}
$$

where $\Delta E_{i, j}$ is the estimated reduction in cropland $\mathrm{Nr}$ emissions, $H \operatorname{Cos} t_{i, j}$ represents the unit health damage cost of $\mathrm{Nr}$ emission (Table S2).

The climate impact of $\mathrm{Nr}$ management is assessed as showed in Eq. (11):

$$
\mathrm{GHG}_{\mathrm{benefit}, i}=\Delta E_{\mathrm{i}, \mathrm{j}} * \mathrm{CCost}_{\mathrm{i}, \mathrm{j}}
$$

where C Cost $_{i, j}$ represents the unit damage cost to climate in US \$ per kg N (Table S2). $\mathrm{N}_{2} \mathrm{O}$ contributes to global warming. $\mathrm{NO}_{\mathrm{x}}$ and $\mathrm{NH}_{3}$ have a cooling effect on the global climate $^{39}$.

\section{Future scenario analysis towards 2050}

To inform future policy making, we explore the cropland nitrogen input and flows towards the year 2050 under different scenarios using the Tier approach. Business as usual (BAU) scenario is a baseline scenario and is assumed with no improvement on cropland management. The other four scenarios were assigned with certain options or measures under Tier approach (Extended Data Table 1). For each option or measure, we assume different adoption rate and mitigation efficiencies by nation based on their status of agriculture, fertilizer application, crop yield, farm size and farmer current income level. Human population (population density) and economic level (per capita gross domestic product (PGDP)) are two key determinants of future food demand and required $\mathrm{Nr}$ harvest from cropland, which are all assumed to be consistent under 
different Tier regulations. It is assumed that the adoption of measures will change the cropland nitrogen input, NUE, cropping area, to maintain the required $\mathrm{Nr}$ harvest for human consumption. Details on data sources, prediction methods and parameters can be found in Supplementary Information.

\section{References:}

1. Erisman, J.W., et al. Consequences of human modification of the global nitrogen cycle. Philos Trans Royal Soc B 368, 20130116 (2013).

2. Sutton, M.A., et al. Our Nutrient World: the challenge to produce more food and energy with less pollution. (Centre for Ecology and Hydrology (CEH), 2013).

3. Gu, B., et al. A Credit System to Solve Agricultural Nitrogen Pollution. The Innovation 2, 100079 (2021).

4. Foley, J.A., et al. Solutions for a cultivated planet. Nature 478, 337-342 (2011).

5. Steffen, W., et al. Planetary boundaries: Guiding human development on a changing planet. Science 347 (2015).

6. Sutton, M.A., et al. Too much of a good thing. Nature 472, 159-161 (2011).

7. Springmann, M., et al. Options for keeping the food system within environmental limits. Nature 562, 519-525 (2018).

8. Zhang, W., et al. Closing yield gaps in China by empowering smallholder farmers. Nature 537, 671-674 (2016).

9. Wu, Y., et al. Policy distortions, farm size, and the overuse of agricultural chemicals in China. Proc Natl Acad Sci USA 115, 7010-7015 (2018).

10. Gu, B., Ju, X., Chang, J., Ge, Y. \& Vitousek, P.M. Integrated reactive nitrogen budgets and future trends in China. Proc Natl Acad Sci USA 112, 8792-8797 (2015). 11. Bodirsky, B.L., et al. Reactive nitrogen requirements to feed the world in 2050 and potential to mitigate nitrogen pollution. Nat Commun 5, 3858 (2014).

12. Bouwman, L., et al. Exploring global changes in nitrogen and phosphorus cycles in agriculture induced by livestock production over the 1900-2050 period. Proc Natl Acad Sci USA 110, 20882-20887 (2013).

13. Zhang, X., et al. Managing nitrogen for sustainable development. Nature 528, 5159 (2015).

14. Pinder, R.W., et al. Climate change impacts of US reactive nitrogen. Proc Natl Acad Sci USA 109, 7671-7675 (2012).

15. Laborde, D., Mamun, A., Martin, W., Piñeiro, V. \& Vos, R. Agricultural subsidies and global greenhouse gas emissions. Nat Commun 12 (2021).

16. Jin, S., et al. Decoupling livestock and crop production at the household level in China. Nature Sustainability 4, 48-55 (2021).

17. Roy, G., Ostrom, E. \& Walker, J.M. The nature of common-pool resource problems. Ration Soc 2, 335-358 (1990).

18. Chamizo-González, J., Cano-Montero, E. \& Muñoz-Colomina, C. Does funding of waste services follow the polluter pays principle? The case of Spain. J Clean Prod 183, 1054-1063 (2018).

19. Chen, X., et al. Producing more grain with lower environmental costs. Nature 514, 486-489 (2014).

20. Ren, C., et al. The impact of farm size on agricultural sustainability. J Clean Prod 220, 357-367 (2019).

21. Ogorevc, M. \& Slabe-Erker, R. Assessment of the European Common Agricultural Policy and landscape changes: an example from Slovenia. Agricultural Economics (Zemědělská ekonomika) 64, 489-498 (2018).

22. Kanter, D.R. \& Searchinger, T.D. A technology-forcing approach to reduce 
nitrogen pollution. Nature Sustainability 1, 544-552 (2018). Taxation: A Review. International Journal of Environment, Agriculture and Biotechnology 2, 1829-1834 (2017). 24. Adams, D.C., Gurevitch, J. \& Rosenberg, M.S. Resampling tests for meta-analysis of ecological data. Ecology 78, 1277-1283 (1997). lower greenhouse gas emission and reactive nitrogen pollution? A meta-analysis. Global Change Biol 23, 1917-1925 (2017).

26. Rosenberg, M., Adams, D. \& Gurevitch, J. eds. MetaWin Version 2: Statistical software for meta-analysis (Sinauer Associates Inc., Sunderland, 2000).

27. Lu, M., et al. Minor stimulation of soil carbon storage by nitrogen addition: A meta-analysis. Agri Eco Environ 140, 234-244 (2011).

28. Lam, S.K., Chen, D., Norton, R., Armstrong, R. \& Mosier, A.R. Nitrogen dynamics in grain crop and legume pasture systems under elevated atmospheric carbon dioxide concentration: A meta-analysis. Global Change Biol 18, 2853-2859 (2012).

29. Guo, L.B. \& Gifford, R.M. Soil carbon stocks and land use change: a meta analysis. Global Change Biol 8, 345-360 (2002).

30. Klimont, Z. \& Winiwarter, W. Integrated ammonia abatement - Modelling of emission control potentials and costs in GAINS. (2011).

31. Leclère, D., et al. Bending the curve of terrestrial biodiversity needs an integrated strategy. Nature 70, 330-342 (2020).

32. Ohashi, H., et al. Biodiversity can benefit from climate stabilization despite adverse side effects of land-based mitigation. Nat Commun 10 (2019).

33. Van Grinsven, H.J.M., et al. Reducing external costs of nitrogen pollution by relocation of pig production between regions in the European Union. Reg Environ Change 18, 2403-2415 (2018).

34. Sobota, D.J., et al. Cost of reactive nitrogen release from human activities to the environment in the United States. Environ Res Lett 10, 25006 (2015).

35. Jones, L., et al. A review and application of the evidence for nitrogen impacts on ecosystem services. Ecosyst Serv 7, 76-88 (2014).

36. Sutton, M.A., et al. Costs and benefits of nitrogen in the environment. in The European Nitrogen Assessment (Cambridge University Press, 2011).

37. Compton, J.E., et al. Ecosystem services altered by human changes in the nitrogen cycle: a new perspective for US decision making. Ecol Lett 14, 804-815 (2011). 38. Benayas, J.M.R., Newton, A.C., Diaz, A. \& Bullock, J.M. Enhancement of Biodiversity and Ecosystem Services by Ecological Restoration: A Meta-Analysis. Science 325, 1121-1124 (2009).

39. Pinder, R.W., et al. Impacts of human alteration of the nitrogen cycle in the US on radiative forcing. Biogeochemistry 114, 25-40 (2013).

\section{Data availability}

Data of the main findings can be found in Supplementary Information. Further data that support the findings of this study are collated from online open databases or literature sources as cited.

\section{Acknowledgements}

This study was supported by the National Natural Science Foundation of China (41822701, 41773068 42061124001 and 41721001). This work is a contribution from Activity 1.4 to the 'Towards the International Nitrogen Management System' project 
495 (INMS, http://www.inms.international/) funded by the Global Environment Facility

496 (GEF) through the United Nations Environment Programme (UNEP).

\section{Author contributions}

499 B.G. designed the study, analyzed all the data, interpreted the results and wrote the first 500 draft and all authors contributed to the discussion and revision of the paper. X.Z. 501 conducted the cost and benefit analysis and scenario projection. S.K.L. conducted the 502 meta-analysis. Y.Y. collected the global data for meta-analysis. H.M.G. and D.C. helped 503 to develop the idea. S.Z. provided the GAINS model for the cost and benefit analysis. 504 X.W and B.L.B. provided the results of MAgPIE model. S.W. and J.D. helped to make 505 the figures. L.B. provided the results of IMAGE model. J.X. and M.A.S. contributed to 506 the discussion of the study.

\section{Additional information}

Extended data is available for this paper.

Supplementary information is available for this paper.
Reprints and permissions information is available at http://www.nature.com/reprints. Correspondence and requests for materials should be addressed to B.G. 
Table 1. Features of different abatement measures

\begin{tabular}{|c|c|c|c|c|c|}
\hline Measures & Potential & Feasibility & Regions & Barriers & Tiers \\
\hline $\begin{array}{l}\text { EEF } \\
\text { Amendment } \\
\text { Legume }\end{array}$ & $\begin{array}{c}-47 \% \\
-9 \% \\
-32 \%\end{array}$ & $\begin{array}{l}\text { Easy to apply, large } \\
\text { reduction potential }\end{array}$ & $\begin{array}{l}\text { All global } \\
\text { regions }\end{array}$ & Financial constraints & 1 \\
\hline $\begin{array}{l}\text { Rate } \\
\text { Type } \\
\text { Time } \\
\text { Placement }\end{array}$ & $\begin{array}{l}-43 \% \\
-23 \% \\
+17 \% \\
-5 \%\end{array}$ & $\begin{array}{l}\text { Require advanced } \\
\text { management and } \\
\text { facilities, middle to large } \\
\text { reduction potential }\end{array}$ & $\begin{array}{l}\text { Middle to } \\
\text { high } \\
\text { income } \\
\text { regions }\end{array}$ & $\begin{array}{l}\text { Large fixed } \text { input } \\
\text { requires large } \\
\text { size }\end{array}$ & 2 \\
\hline $\begin{array}{l}\text { Tillage } \\
\text { New } \\
\text { cultivar } \\
\text { Irrigation }\end{array}$ & $\begin{array}{l}+11 \% \\
+2 \% \\
-37 \%\end{array}$ & $\begin{array}{l}\text { Well trained farmers and } \\
\text { advanced technologies, } \\
\text { unstable } \\
\text { potential reduction }\end{array}$ & $\begin{array}{l}\text { High- } \\
\text { income } \\
\text { regions }\end{array}$ & $\begin{array}{l}\text { Inconsistent reduction } \\
\text { requires local } \\
\text { experiments }\end{array}$ & 3 \\
\hline Buffer zone & $-14 \%$ & $\begin{array}{l}\text { Wealthy farmers with } \\
\text { good environmental } \\
\text { awareness and willingness } \\
\text { to pay for environment } \\
\text { protection }\end{array}$ & $\begin{array}{l}\text { High- } \\
\text { income } \\
\text { regions }\end{array}$ & $\begin{array}{l}\text { High cost but low } \\
\text { benefit to farmers, } \\
\text { despite } \\
\text { environmental } \\
\text { benefits } \\
\text { len }\end{array}$ & 4 \\
\hline
\end{tabular}

517 EEF refers to enhanced efficiency fertilizers; Amendment refers to amendment applied 518 to croplands such as biochar; Legume refers to rotation of legume with other crops; 519 Rate, type, time and placement refers to the right fertilizer amount, right fertilizer type, 520 right time and right placement on fertilization; Tillage refers to change of tillage to non521 tillage; Irrigation refers to drip irrigation or optimal irrigation to reduce fertilizer loss; 522 Buffer zone refers to the utilization of wetlands or marginal lands between croplands 523 and rivers. Potential refers to the overall potential on reduction of nitrogen loss and is 524 estimated based on the reduction potential of each nitrogen loss pathway $\left(\mathrm{NH}_{3}, \mathrm{NO}_{\mathrm{x}}\right.$, $525 \mathrm{~N}_{2} \mathrm{O}$, runoff and leaching) weighted using their global nitrogen fluxes. More details of each measure can be found in Table S3 and Fig. S1-S11. 


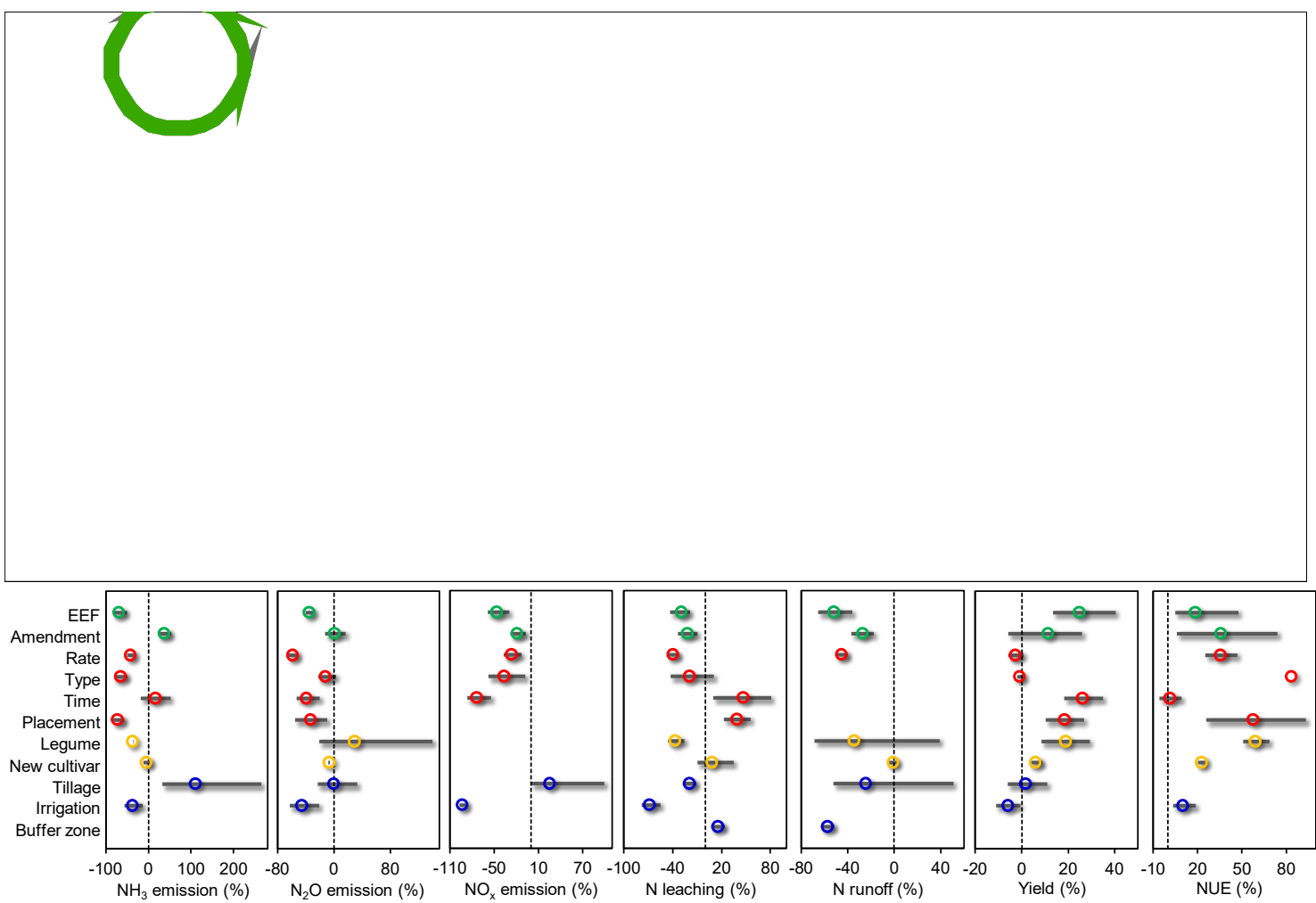

Fig. 1 Distribution of the sample sites of the global meta-analysis and the effects of management practices on cropland nitrogen use and loss. 4R refers to the right fertilizer type, right amount, right placement, and right time on fertilization; EEF refers to enhanced efficiency fertilizers; Amendment refers to amendment applied to croplands such as biochar; Tillage refers to change of tillage to non-tillage; Legume refers to rotation of legume with other crops; Irrigation refers to drip irrigation or optimal irrigation to reduce fertilizer loss; Buffer zone refers to apply wetlands or marginal lands between croplands and rivers. The colors in meta-analysis refer to different types of measures: additive (green), 4R nutrient stewardship (red), crop species (yellow) and biophysical management (blue). Base map is applied without endorsement from GADM data (https://gadm.org/). 


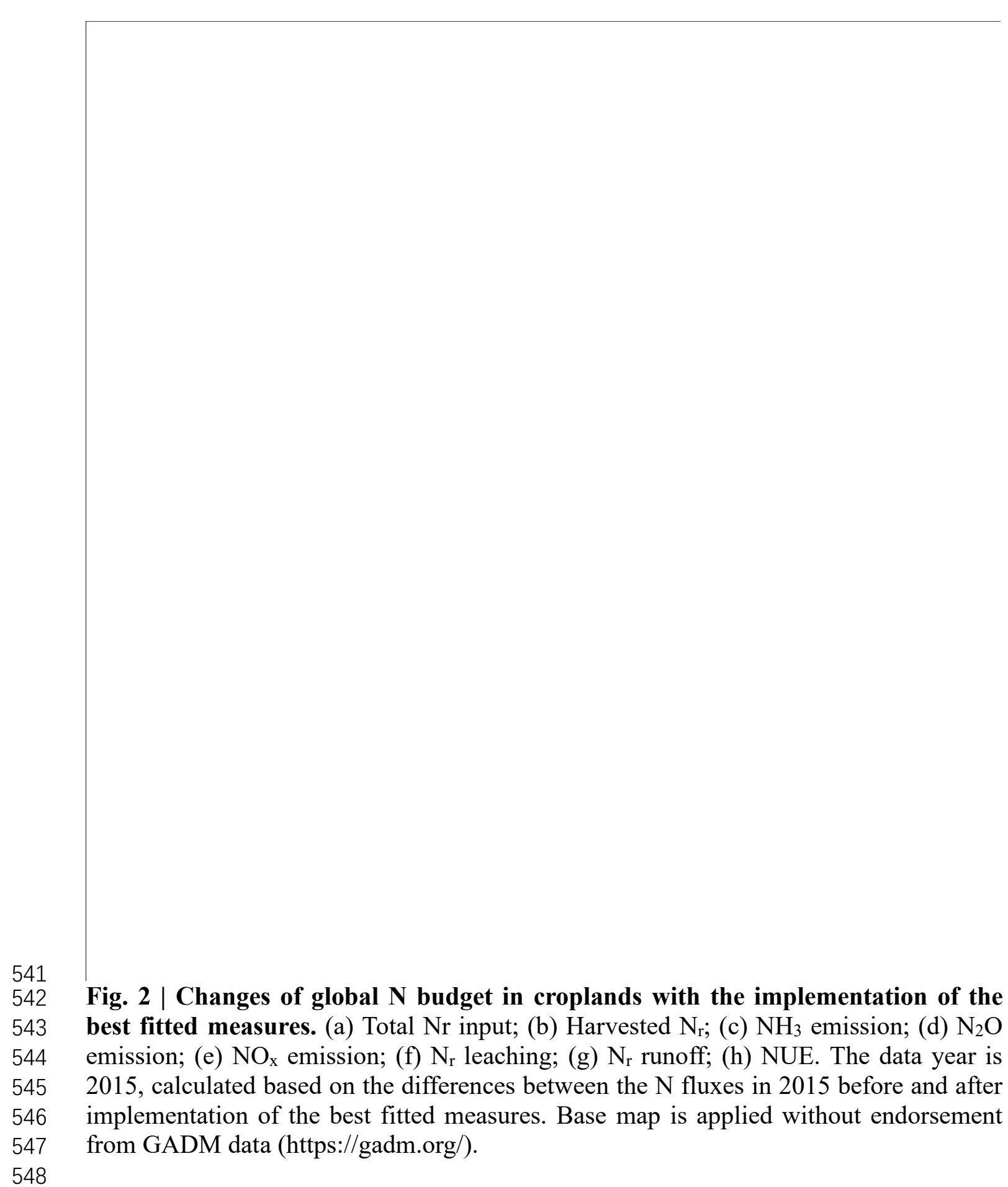



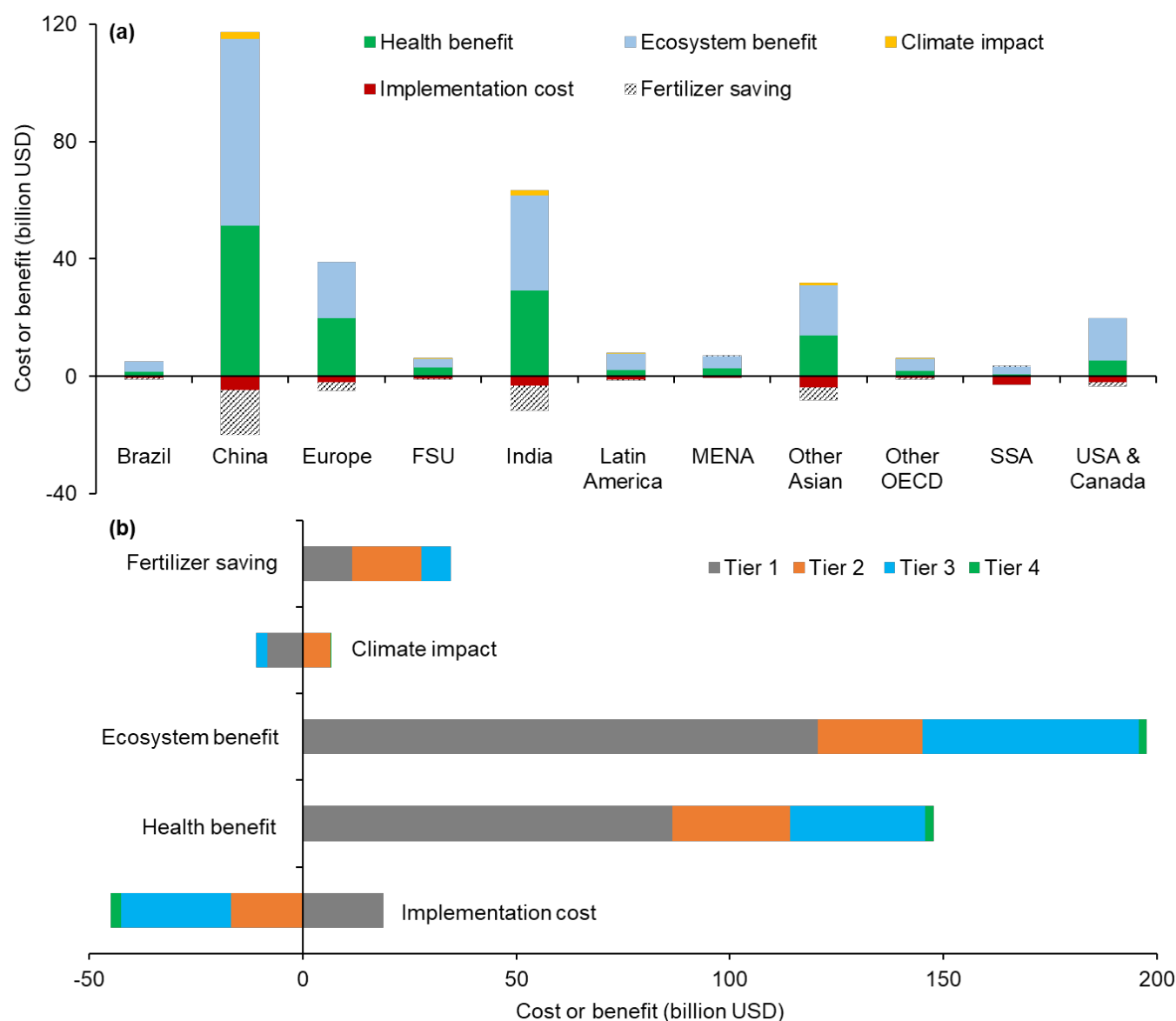

Cost or benefit (billion USD)

550 Fig. 3 | Costs and benefits of implementation of the best fitted measures. (a)

551 Variations in major global regions in 2015; (b) Variations under different Tiers 552 compared to the business as usual scenario in 2050 (see method). Implementation cost 553 refers to the net cost farmers still needed on the implementation of the NCS other than 554 fertilizer saving, and negative values refer to cost and positive values refer to benefit. It 555 suggests that implementing Tier 1 measures can save cost on crop production, while 556 other Tiers require extra financial support. FSU, Former Soviet Union; MENA, Middle 557 East and North Africa; SSA, Sub-Saharan Africa. 
(a)
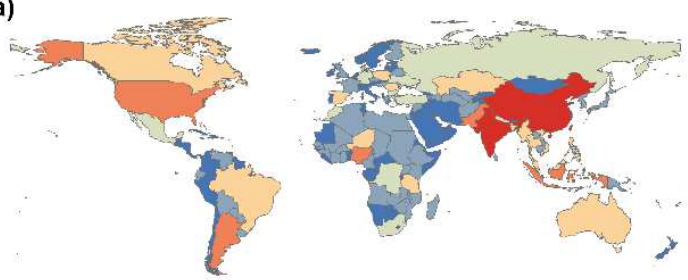

Total abatement cost (billion \$)

(c)
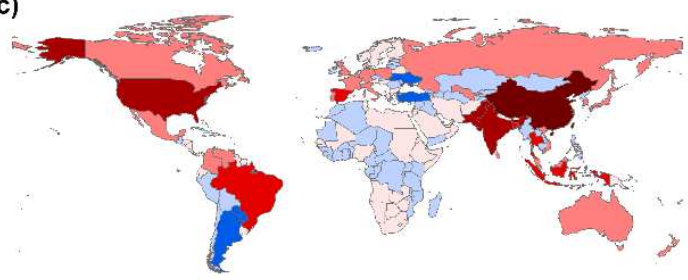

Fertilizer saving (billion \$)

(e)

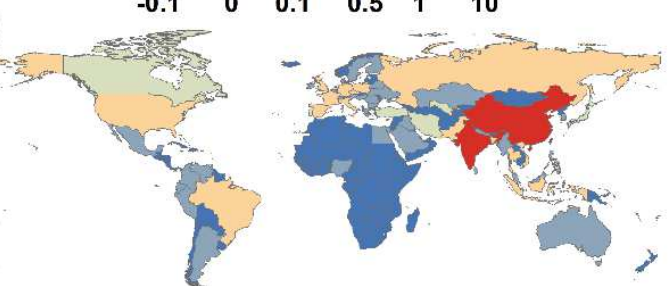

Health benefit (billion \$) (b)

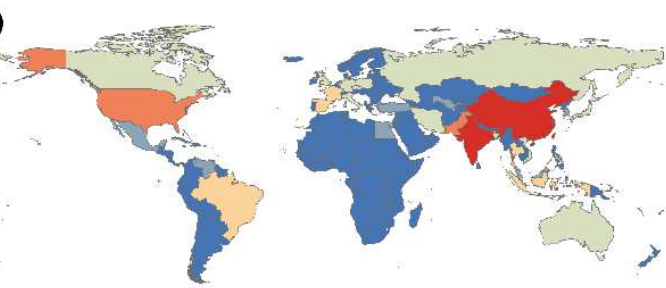

Total benefit (billion \$)

(d)

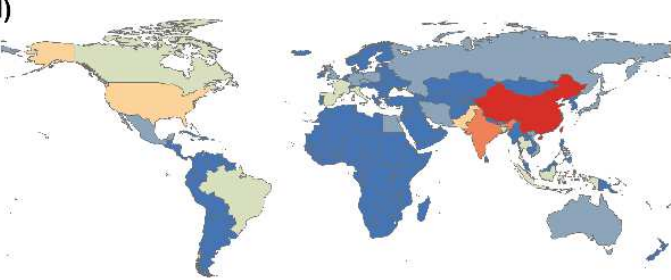

Ecosystem benefit (billion \$)

(f)

$\begin{array}{llllll}0 & 1 & 2 & 5 & 20 & 50\end{array}$
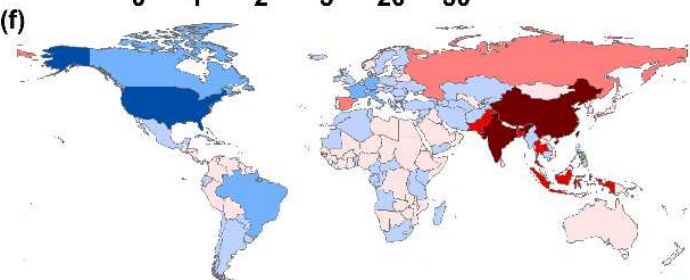

Net climate benefit (billion \$)

$\begin{array}{llllllll}-0.2 & -0.1 & -0.05 & 0 & 0.05 & 0.1 & 0.5 & 1\end{array}$

Fig. 4 Costs and benefits of the implementation of the best fitted measures in different countries. (a) Total abatement cost; (b) Total benefit; (c) Fertilizer saving; (d) Ecosystem benefit; (e) Health benefit; (f) Net climate benefit. Units are billion USD. Base map is applied without endorsement from GADM data (https://gadm.org/). 

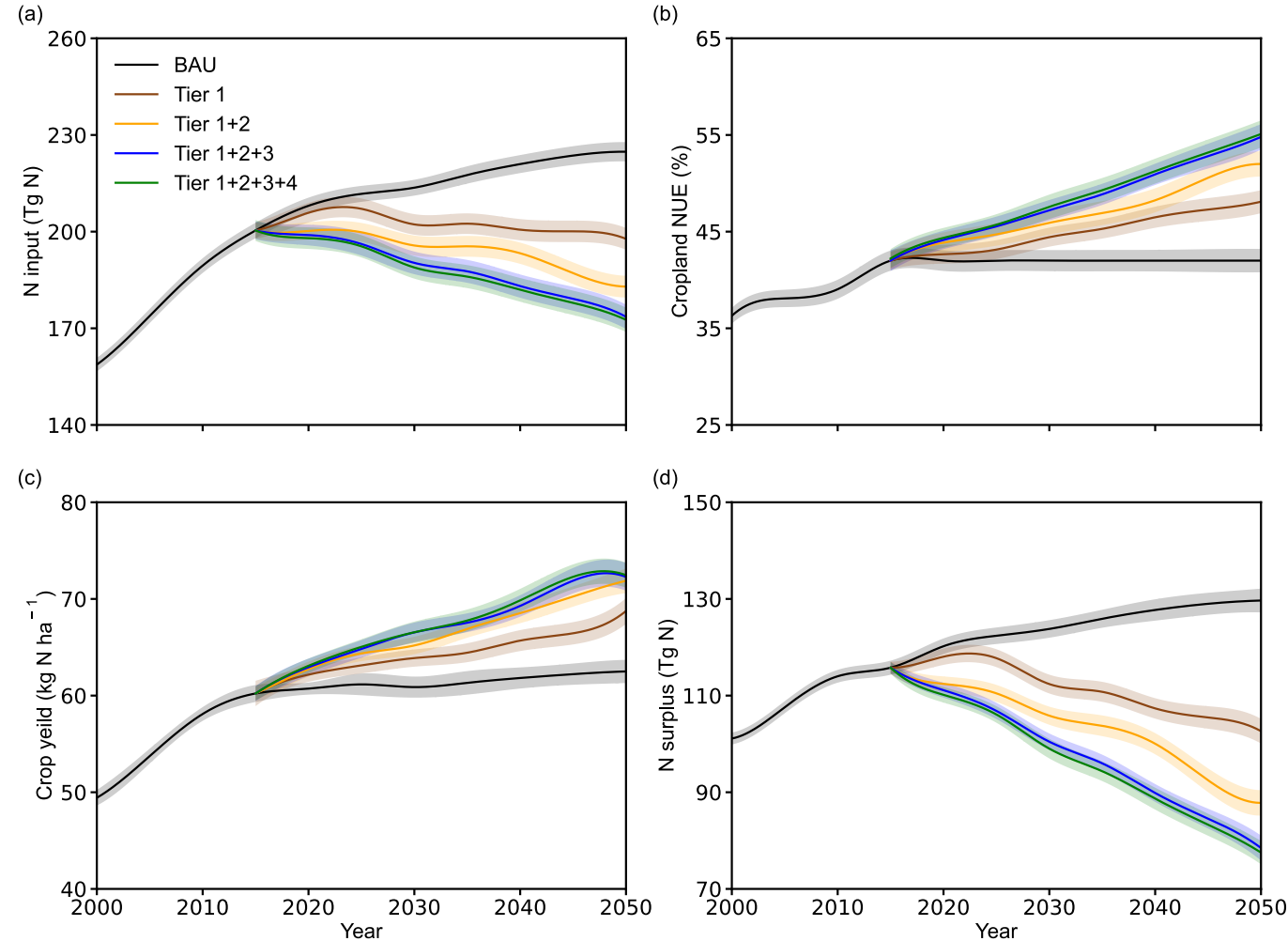

Fig.5 | Global cropland nitrogen input and its flows under Tier approach towards 2050. (a) Cropland $\mathrm{N}$ input; (b) Cropland NUE; (c) Crop yield; (d) $\mathrm{N}$ surplus. N, nitrogen. The shadow behind each line refers to $95 \%$ confidence interval. More details about the scenario settings could be found in Extended Data Table 1. 


\begin{tabular}{ll}
\hline Scenario & Description \\
\hline BAU & The world develops into one that is unequal and fragmented. \\
& Lifestyles are materialistic and consumption-oriented, resulting in \\
& food waste and livestock consumption which is relatively high. \\
& There is little investment into farming practices and technology, \\
& leading to no improvements in agricultural production efficiency. \\
& Trade is low, and there is no efficient regulation of land-use change. \\
Tier 1 & The three options are preferentially adopted by farmers regarding \\
Tiers 1+2 & cost feasibility and efficiency. \\
& Based on Tier 1, 4R stewardships with efficient technologies in \\
& fertilizer application are further implemented to varying degrees by \\
& nation due to a high heterogeneity of best-practices on the local \\
Tiers 1+2+3 & scale, and high implementation cost for farmers. \\
& Based on Tier 1+2 regulations, Tier 3 regulations will further \\
& implement regional specific tillage, irrigation, and new cultivar \\
& options leading to improvements in agricultural production \\
efficiency. More advanced knowledge and facilities are required, & \\
& which usually can only be adopted by professional farmers with \\
large-scale farming. & Based on Tier 1+2+3 regulations, Tier 4 requires more advanced \\
knowledge and financial support to ensure the sustainability and \\
$\mathbf{1 + 2 + 3 + 4}$ & resilience of the cropland system through such as buffer zone.
\end{tabular}

BAU, business as usual. 4R refers to the right fertilizer type, right amount, right placement, and right time on fertilizer application. 
(a)

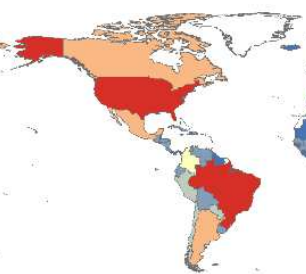

$2015 \mathrm{Nr}$ input (Tg N)

(c)
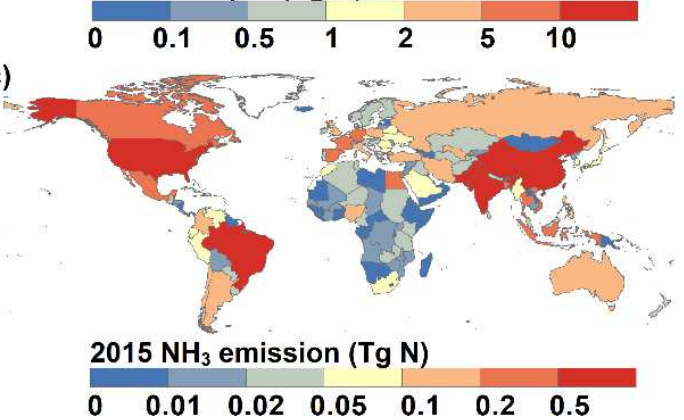

(e)

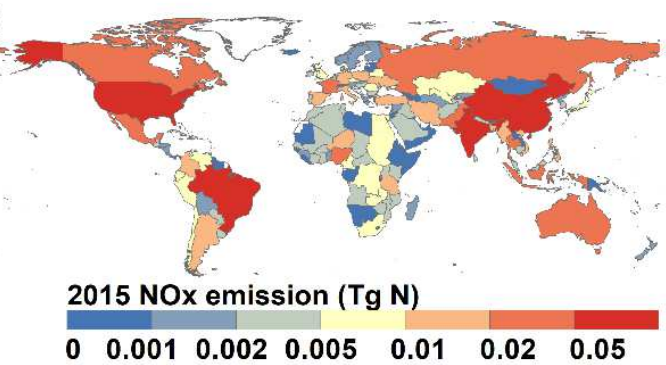

(g)

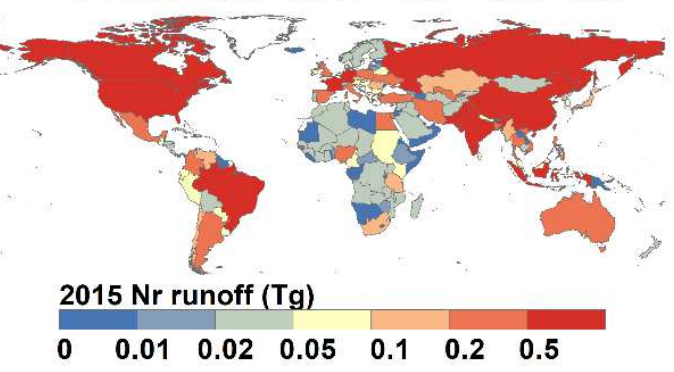

(b)

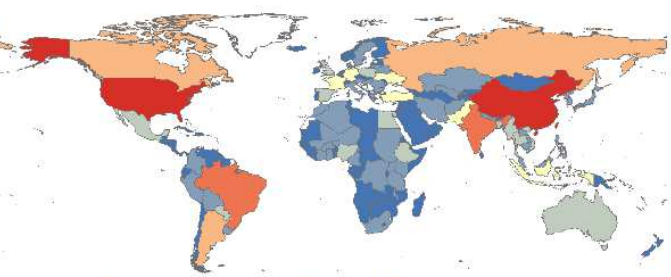

2015 harvested $\mathrm{Nr}(\mathrm{Tg} \mathrm{N})$

(d)

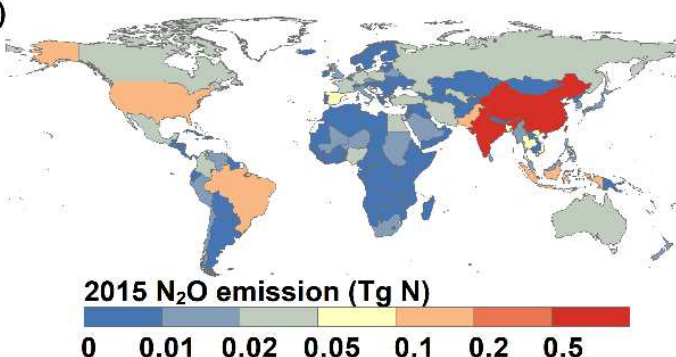

(f)

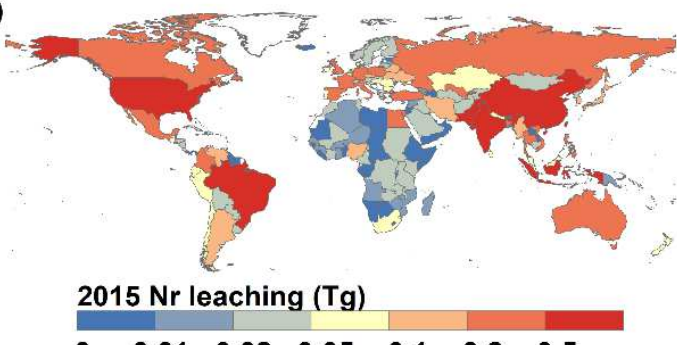

(h)

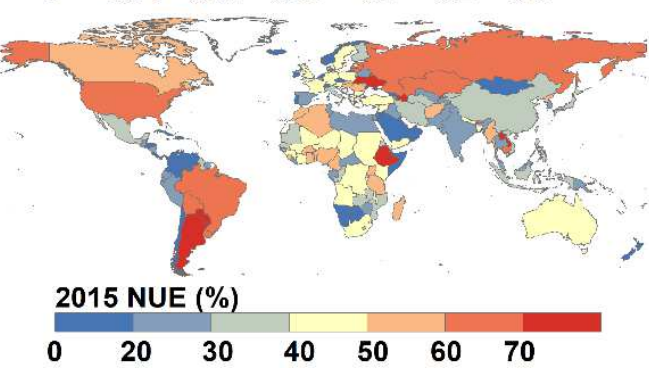

Extended Data Fig.1 | Nitrogen budget of croplands on country scale in 2015. (a) $\mathrm{Nr}$ input; (b) Nr harvested; (c) $\mathrm{NH}_{3}$ emission; (d) $\mathrm{N}_{2} \mathrm{O}$ emission; (e) NOx emission; (f) $\mathrm{Nr}$ leaching; (g) Nr runoff; (h) NUE. Base map is applied without endorsement from GADM data (https://gadm.org/). 
(a)

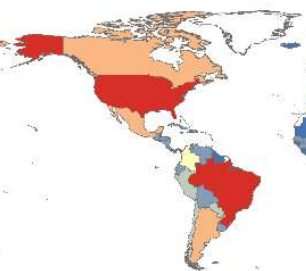

Required $\mathrm{Nr}$ input $(\mathrm{Tg} \mathrm{N})$

(c)

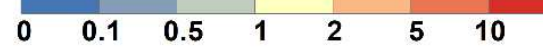

(c)

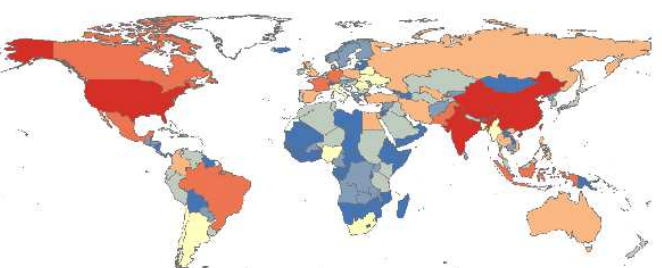

Optimal $\mathrm{NH}_{3}$ emission $(\operatorname{Tg~N})$

$\begin{array}{lllllll}0 & 0.01 & 0.02 & 0.05 & 0.1 & 0.2 & 0.5\end{array}$

(e)

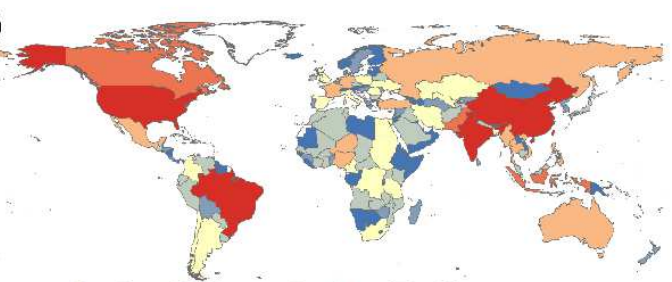

Optimal NOx emission $(\mathrm{Tg} \mathrm{N})$

$\begin{array}{lllllll}0 & 0.001 & 0.002 & 0.005 & 0.01 & 0.02 & 0.05\end{array}$

(g)

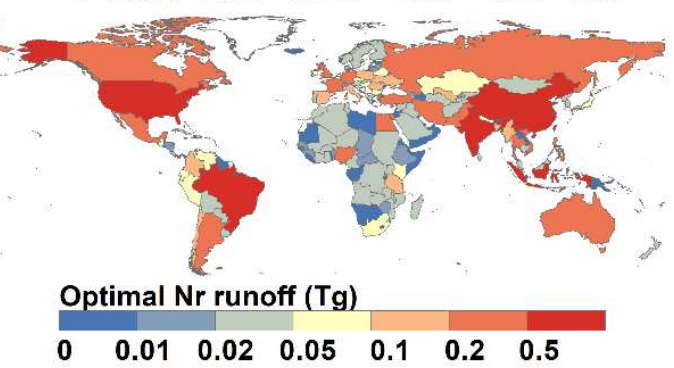

(b)

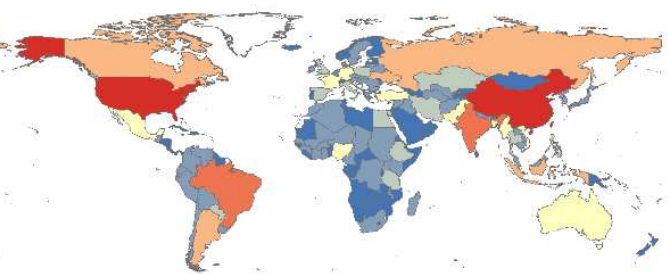

Target harvested $\mathrm{Nr}(\mathrm{Tg} \mathrm{N})$

(d)
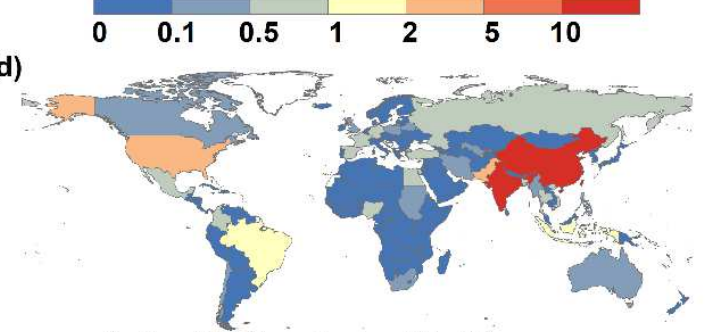

Optimal $\mathrm{N}_{2} \mathrm{O}$ emission $(\operatorname{Tg~N})$

(f)

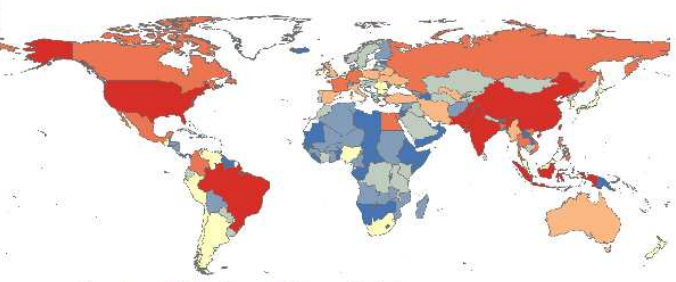

Optimal $\mathrm{Nr}$ leaching $(\mathrm{Tg})$

(h)

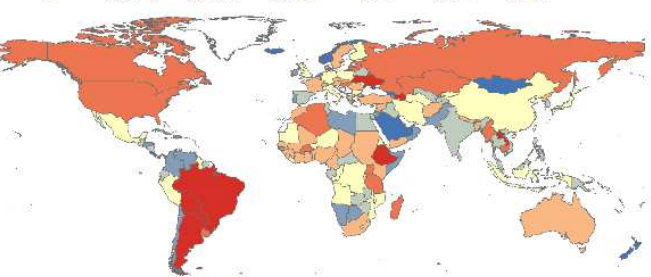

Targeted NUE (\%)

$\begin{array}{lllllll}0 & 20 & 30 & 40 & 50 & 60 & 70\end{array}$
Extended Data Fig.2 | Optimized nitrogen budget on croplands on country scale. (a)

$\mathrm{Nr}$ input; (b) Nr harvested; (c) $\mathrm{NH}_{3}$ emission; (d) $\mathrm{N}_{2} \mathrm{O}$ emission; (e) NOx emission; (f) $\mathrm{Nr}$ leaching; (g) Nr runoff; (h) NUE. Base map is applied without endorsement from GADM data (https://gadm.org/). 


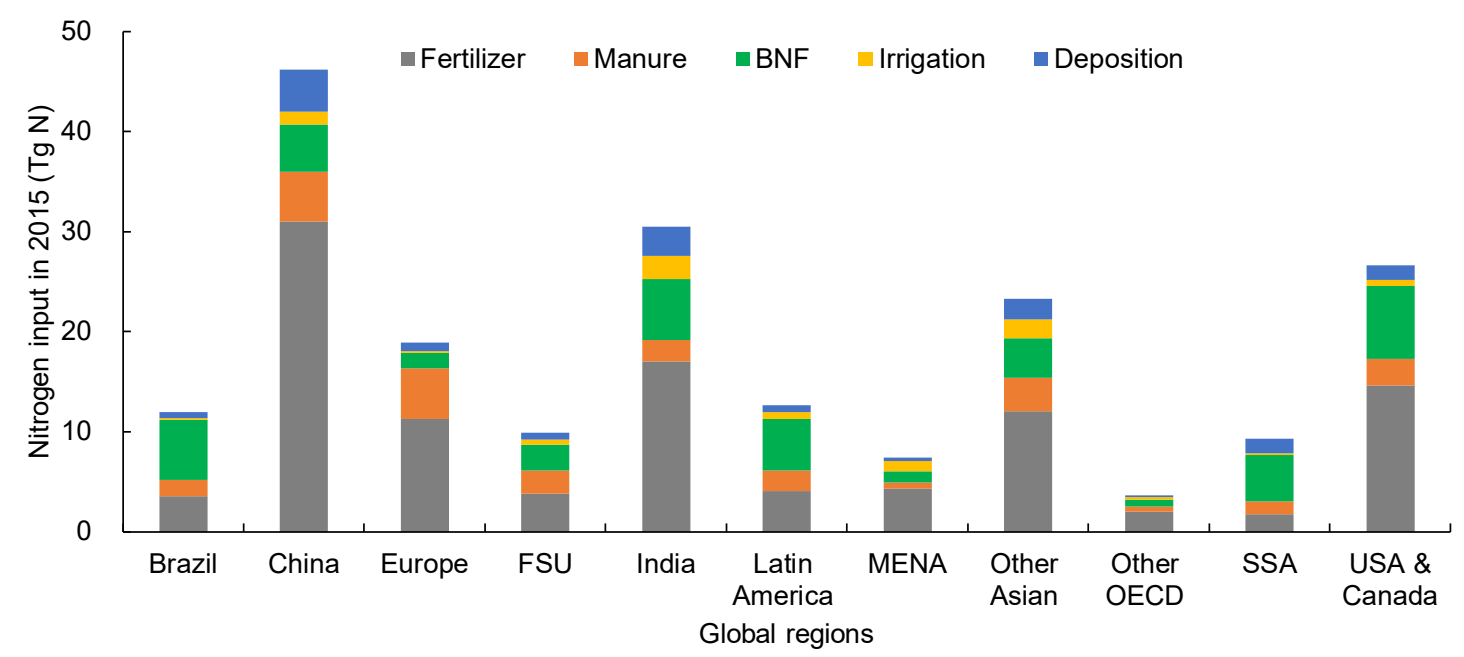

Extended Data Fig.3 | Nitrogen input to croplands in 2015 in major global regions.

590 FSU, Former Soviet Union; MENA, Middle East and North Africa; SSA, Sub-Saharan 591 Africa. 
(a)
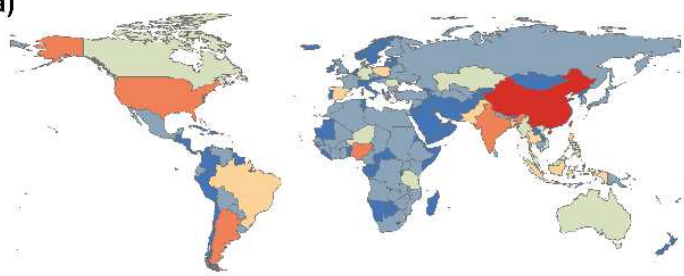

Lower limit of total abatement cost (billion \$)

(c)
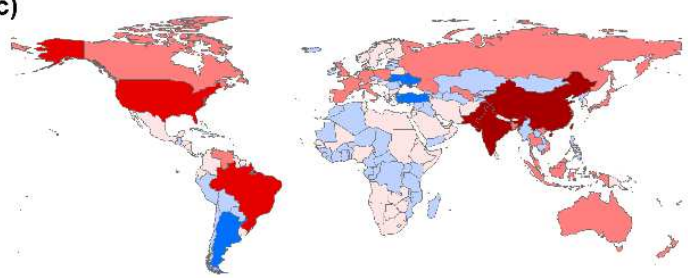

Lower limit of fertilizer saving (billion \$)

(e)

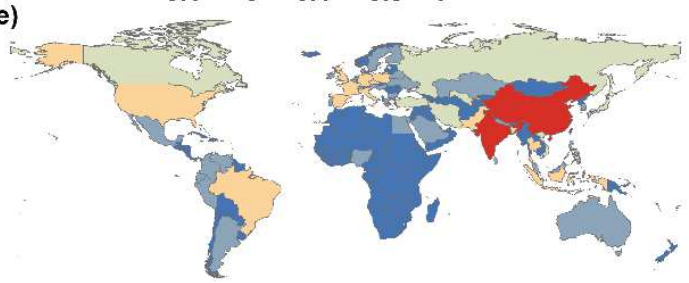

Lower limit of health benefit (billion \$) (b)

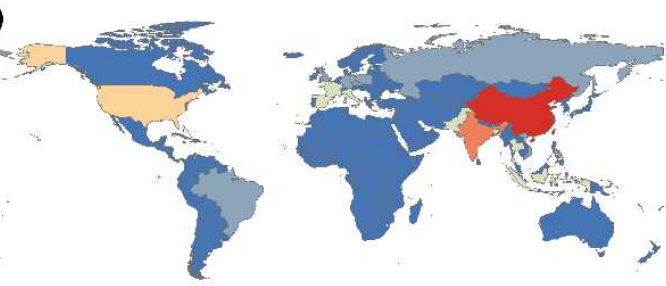

Lower limit of total benefit (billion \$)

(d)

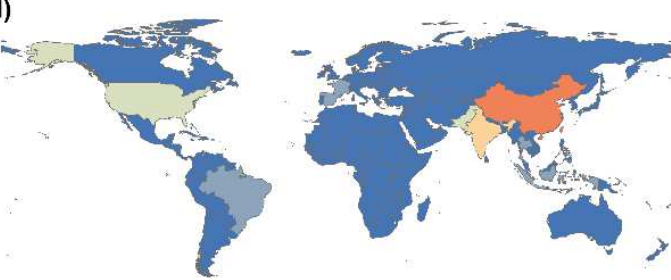

Lower limit of ecosystem benefit (billion \$)
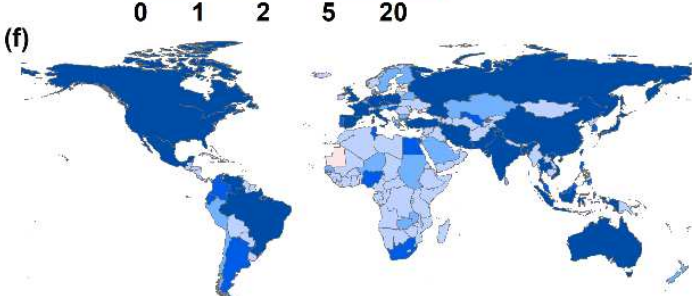

Lower limit of net climate benefit (billion \$) $\begin{array}{llll}-0.2 & -0.1 & -0.05 & 0\end{array}$

Extended Data Fig. 3 | Lower limits of cost and benefit of nitrogen pollution abatement in croplands on country scale. (a) Total abatement cost; (b) Total benefit; (c) Fertilizer saving; (d) Ecosystem benefit; (e) Health benefit; (f) Net climate benefit. Base map is applied without endorsement from GADM data (https://gadm.org/). 
(a)

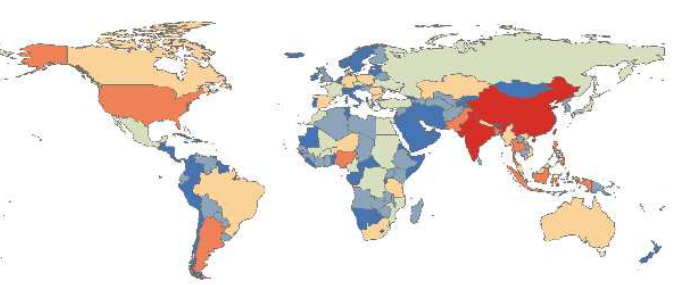

Upper limit of total abatement cost (billion \$)

(c)
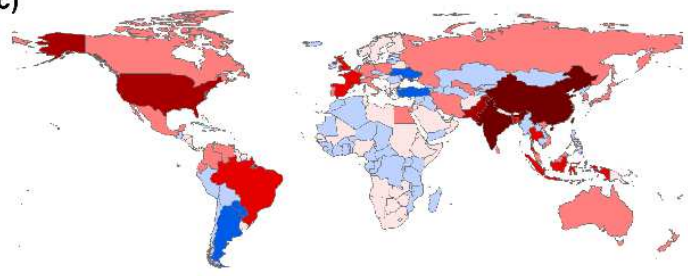

Upper limit of fertilizer saving (billion \$)

(e)

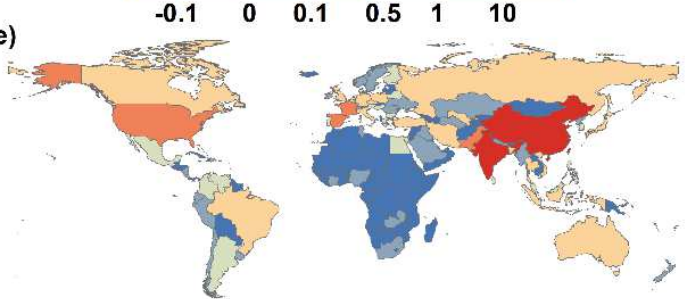

Upper limit of health benefit (billion \$) (b)

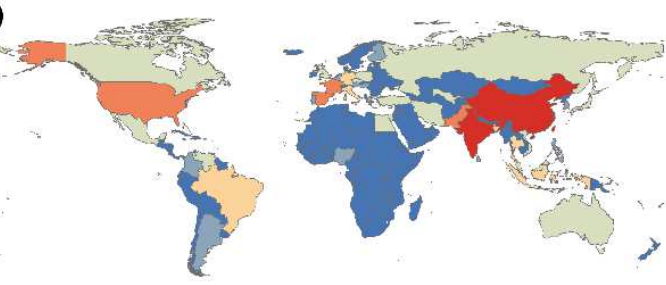

Upper limit of total benefit (billion \$)

(d)

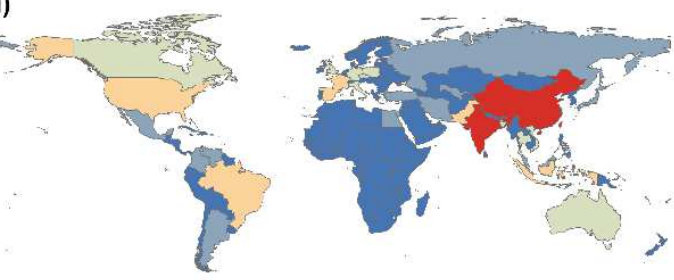

Upper limit of ecosystem benefit (billion \$)

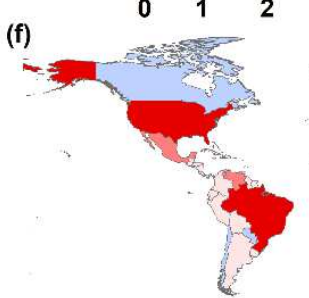

Upper limit of net climate benefit (billion \$)

$\begin{array}{llllll}-0.05 & 0 & 0.05 & 0.1 & 0.5 & 1\end{array}$

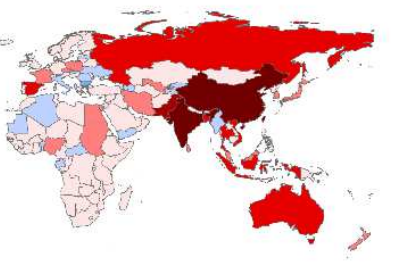

\section{Extended Data Fig. 4 | Upper limits of cost and benefit of nitrogen pollution}

600 abatement in croplands on country scale. (a) Total abatement cost; (b) Total benefit; (c) Fertilizer saving; (d) Ecosystem benefit; (e) Health benefit; (f) Net climate benefit. Base map is applied without endorsement from GADM data (https://gadm.org/). 


\section{Supplementary Files}

This is a list of supplementary files associated with this preprint. Click to download.

- SINcredit.docx 